\title{
Innovation in Innovation Management: the Experience of Petrobras Centers and Networks of Excellence Program
}

\author{
Ana Maria de Britto Pires', Francisco Lima Cruz Teixeira ${ }^{2}$, Horacio Nelson Hastenreiter Filho ${ }^{3}$, Sergio \\ Ricardo Goes Oliveira ${ }^{4}$
}

\begin{abstract}
Since 1996, Petrobras - Petróleo Brasileiro S.A., the biggest company in Latin America, has supported the development of a method to structure networks of partnerships called Centers and Networks of Excellence Practice (PCREX). It aims to support the establishment of centers and networks of excellence in areas in which innovation depends heavily on the articulation of various players from outside the company and different internal areas. This article presents the results of the analysis of the PCREX method, including its characterization and field research carried out in eight Centers and Networks of Excellence developed by Petrobras. The field research and subsequent analysis helped identify (i) the alignment between the PCREX method and the best innovation management practices and (ii) the difficulties faced by new management models based on resource and knowledge sharing, which highlights that organizational innovations need to be able to count on strong institutional support to succeed.
\end{abstract}

Keywords: innovation; innovation management; knowledge networks; center and networks of excellence.

Escola de Administração, Universidade Federal da Bahia (UFBA), Av. Reitor Miguel Calmon, s/n - Vale do Canela Salvador - Bahia - Brazil Zip Code: 40 I 10-90. Phone: (55 7I) 3283.7309. E-mail: I anambpires@gmail.com, ${ }^{2}$ francisco.teixeira73I@gmail.com, ${ }^{3} \mathrm{hnhfilho@gmail.com.}$ ${ }_{4}^{4}$ Mestrado em Administração, Universidade Salvador, Rua Dr. José Peroba, 25I - Stiep / CEP: 4I770-235 - Salvador - Bahia - Brazil. Phone: (55 7I)3273-8595. E-mail: sergio.goes@pro.unifacs.b 


\section{Introduction}

Since 1996, Petrobras - Petróleo Brasileiro S.A., the biggest company in Latin America, has supported the development of a method to structure networks of partnerships called Centers and Networks of Excellence Practice (PCREX). It aims to support the establishment of centers and networks of excellence in areas in which innovation depends heavily on the articulation of various players from outside the company and different internal areas. The PCREX method consists of the mobilization of a set of physical, financial and knowledge resources, technologies and tools, which are brought together focusing on reaching supremacy in a particular knowledge field and developing high quality products, processes and/or services to be used by the partner companies and/or made available to the marketplace.

Traditionally, innovation management models adopt an "offer" approach (science push) which assumes that innovation results from a simple, linear and sequential process that starts with Research and Development (R\&D) activities done inside companies and scientific and technological institutions and ends in the marketplace. The market is seen as the receptacle, the receiver of R\&D results. More recently however, organizations have adopted different ways to manage their technological innovation process. First of all, they have recognized that innovation is not an exclusive activity of R\&D departments. On the contrary, most successful companies struggle to build highly interactive processes among different departments to incorporate information and knowledge from different areas into their innovation effort; such interaction has been considered important dynamics for innovation development. Secondly, the interactions include connections with the external world: the supply-chain, the customers, and the Science and Technology infrastructure. This process includes parallel development with integrated teams, strong interaction with suppliers and leading-customers, emphasis on the interaction of R\&D and production (engineering and manufacturing) and horizontal collaboration (cooperative research, joint-ventures, etc.). This interactive model may help surpass the initial understanding of innovation as a simple linear process referred to here as the "offer" mode.

Based on observations of these new ways of managing the innovation process, Chesbrough (2006) proposed the Open Innovation Model as the most suitable approach to handle the increasing complexity of knowledge required by the innovation process. The central idea is that nowadays no company alone is capable of developing all the solutions for the complex problems they struggle to solve. The emphasis is on building partnerships to exploit new opportunities, capitalizing on all the possibilities made available by the advances in the company's knowledge base.

This article presents the results of the analysis of the PCREX method, a description of it and field research carried out in eight Centers and Networks of Excellence developed by Petrobras. The field research and subsequent analysis helped identify (i) the alignment between the PCREX method and the best innovation management practices and (ii) the difficulties faced by new management models based on resource and knowledge sharing, which highlights that organizational innovations need to be able to count on strong institutional support to succeed.

Initially, a literature review on innovation management and knowledge networks is done. Then, the methodological pro-

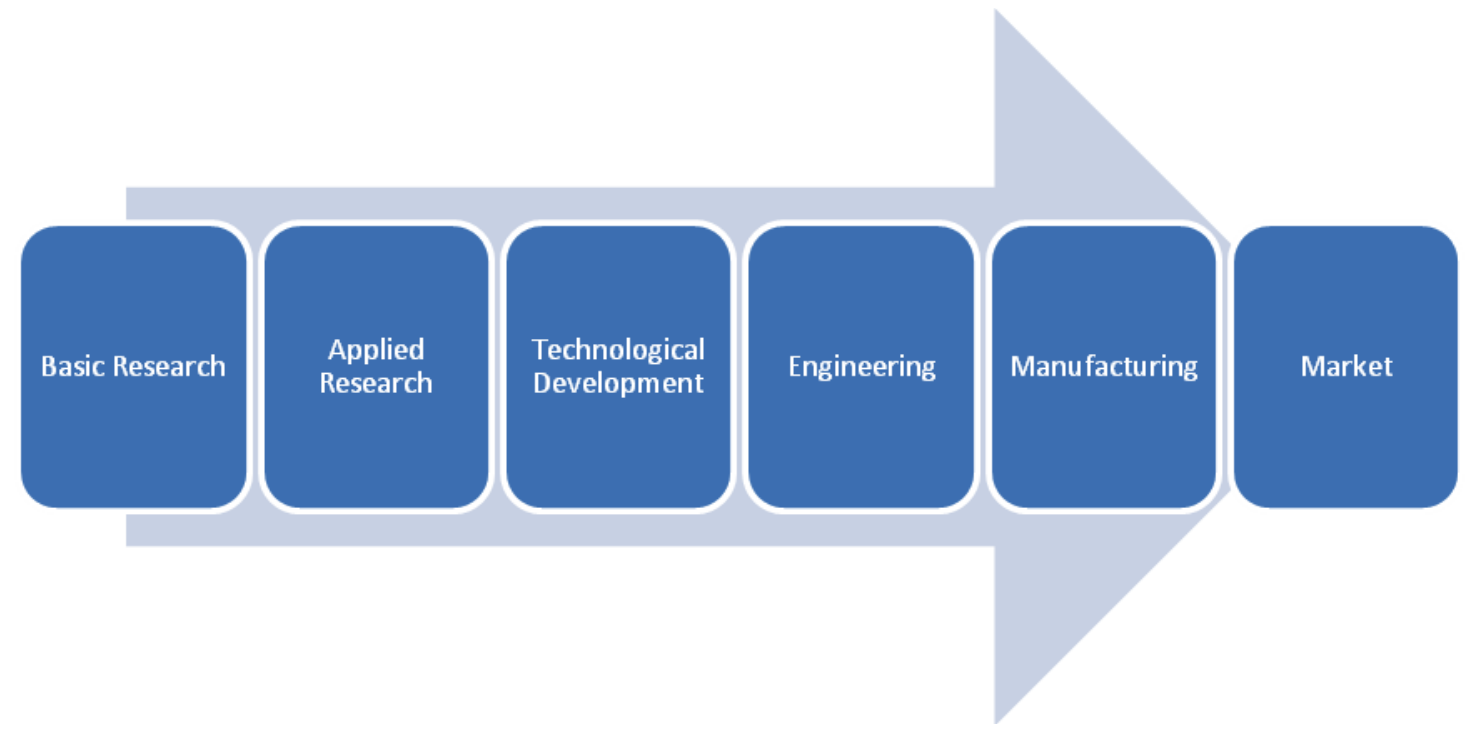

Figure I:“Offer" approach to innovation management. Adapted from Rothwell (1994)

ISSN: 07 I8-2724. (http://www.jotmi.org)

Journal of Technology Management \& Innovation (c) Universidad Alberto Hurtado, Facultad de Economía y Negocios. 
cedures of the field research are described. Next, the analysis of the PCREX method in the light of modern models of innovation management is carried out, followed by the results of the research and the development history of the studied Centers and Networks of Excellence. Finally, the conclusions are presented, including possible lessons for structuring open innovation networks.

\section{Innovation Management}

The traditional "offer" approach to innovation understands that each phase of the innovation process is done by a different type of organization that pushes the results of its efforts down to the next phase in a linear sequential flow as shown in Figure I.

In such a model, the market is seen as the receptacle of the results of R\&D activities done inside companies. According to Rothwell (1994), this science push model has undergone several changes over time. As the market became the main driver of R\&D projects, innovation management adopted a demand pull approach. However, this change did not alter the understanding of innovation as a simple, linear, sequential process. In the 90s, Rothwell (1994) presented a new interactive approach to innovation management which he named The "Coupling" Model of Innovation, which constitutes an alternative to the "offer" model. The "coupling" model involves logic sequences of activities which can be divided into interactive interdependent stages throughout the innova- tion process. Figure 2 represents the interactive dynamic of the "coupling" model.

Based on these observations about how to manage the innovation process in successful enterprises, the authors propose the Open Innovation model as the most appropriate approach for dealing with the increasing complexity of knowledge required by the innovation process (Chesbrough, 2006). Spurring the innovation process through the interaction of the company with external sources of knowledge and technology is the research topic of the Open Innovation theorists, who consider this model a conceptual frame to manage the company innovation efforts (Chesbrough, 2006). Open Innovation focuses on the generation of new value through the intensification of the flow of knowledge and technologies in research, development and innovation activities (RD\&I).

The basis on which to build the conceptual model of Open Innovation is the assumption that a company alone is unable to match the fast dynamics of knowledge creation and diffusion in the networked society, regardless of the maturity of its R\&D activities. Therefore Open Innovation accepts as a premise the opening of the innovation process (Huizingh, 20I I). The subjacent logic admits that companies need to engage in collaborative networks to survive and grow in complex contexts. Networking would facilitate the absorption and the production of knowledge, the development of new technologies, the identification of new uses

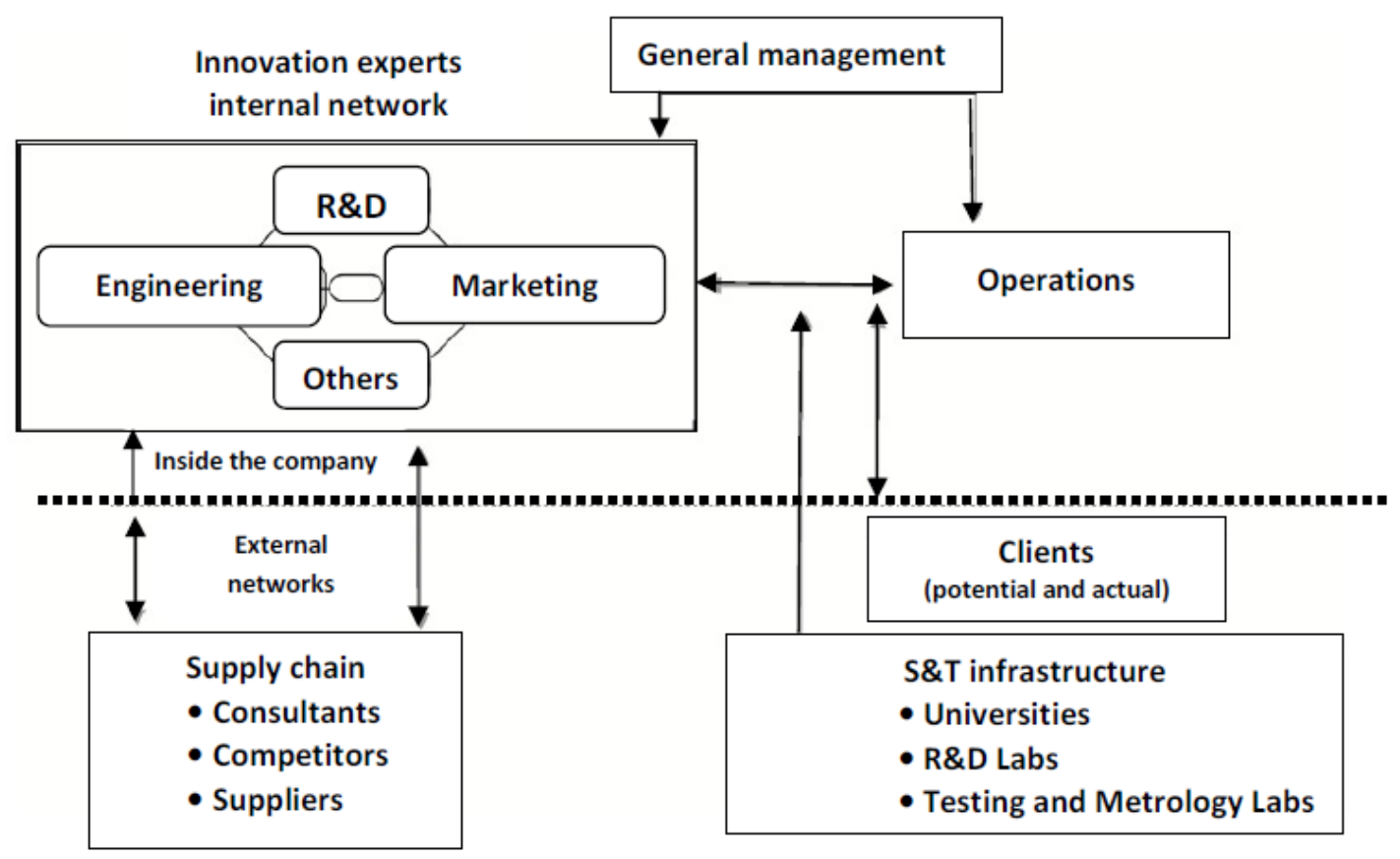

Figure 2: Network of Interactions for Innovation

ISSN: 07 I8-2724. (http://www.jotmi.org)

Journal of Technology Management \& Innovation (c) Universidad Alberto Hurtado, Facultad de Economía y Negocios. 
for existing technologies, the commercialization of new products and services or simply access to new ideas, understandings and technological and scientific developments (Chesbrough, 2006). Figure 3 represents Open Innovation dynamics, highlighting thepermeability of thecompany's boundaries and its interactions with the external environment in RD\&l activities.

According to Chesbrough (2006), Open Innovation proposes the purposeful use of inflows and outflows of knowledge and technologies in the innovation process in order to accelerate it and expand the markets for the knowledge, ideas and innovation generated in R\&D activities. The Open Innovation model identifies two different dimensions with direct impacts on the profitability of the RD\&l investments: the outside-in and the inside-out flows. From the outside-in perspective, companies should exploit more intensively external sources in its innovative process: by bringing resources together, the players can reduce individual costs, time-tomarket and the risks associated with the innovation process, and also broaden the chances to identify new business opportunities. From the inside-out perspective, companies should focus on capitalizing on their Intellectual Property portfolios, trading proprietary ideas and technologies which have already been appropriated internally or which they have no interest in using in their own businesses, but which could mean potential sources of new value generation when combined with external ideas and technologies.

The key features of the Open Innovation dynamic are (i) abundant underlying knowledge landscape (ii) equal importance given to external knowledge compared to internal knowledge (iii) the centrality of the business model in converting R\&D into commercial value (iv) purposeful inflows and outflows of knowledge and technology in the innovation process ( $v$ ) proactive and nuanced role of IP management (vi) proactive management of R\&D errors (vii) the rise of innovation intermediaries and (vii) new metrics for assessing innovation capability and performance (Chesbrough,Vanhaverbeke and West, 2006).

According to Chesbrough (2006), Open Innovation represents a new business model. Whether to adopt it or not is a strategic decision which should be jointly made by people from the departments of marketing, finance, $R \& D$, production and legal affairs. The adoption of an open model of innovation means breaking with the traditional way of thinking and internally structuring RD\&I activities Such a move potentially provokes cultural changes and changes in the power structure and, therefore, tends to face severe resistance. This transformation requires new processes, new metrics for assessing performance, a vast review of the business model in place and a disruption of consolidated concepts and innovation and intellectual property.

Innovation management from the Open Innovation perspective tends to be facilitated by Web 2.0 tools, which have been impacting the way people communicate and interact dramatically. Although the use of these interactive internetbased technologies, such as wikis, blogs and social networks, is still in the initial phase of diffusion and learning in the organizational environment, they may facilitate the identification of internal and external sources of relevant knowledge, the construction of alliances and partnerships, the promo-

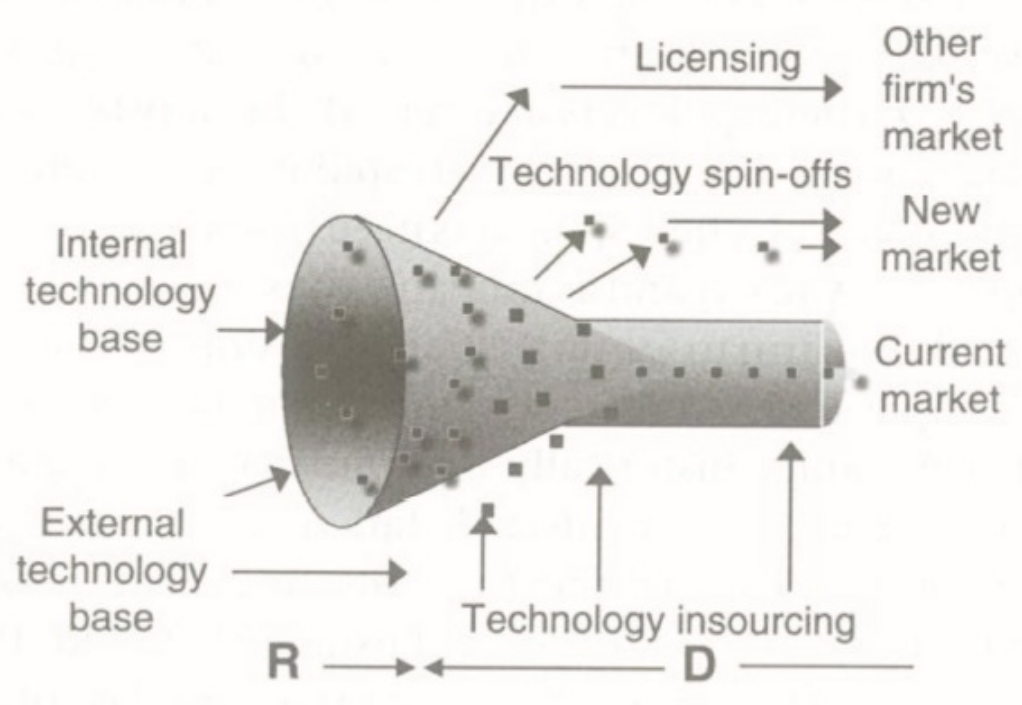

Figure 3: Inflows and Outflows of ideas and technologies in the Open Innovation Model. Data from Chesbrough, Vanhaverbeke and West (2006)

ISSN: 07 I8-2724. (http://www.jotmi.org)

Journal of Technology Management \& Innovation (c) Universidad Alberto Hurtado, Facultad de Economía y Negocios. 
tion of interaction, the combination of expertise, the appropriation of the new knowledge generated and its diffusion throughout the organization, supporting the critical stages of knowledge management (Standing and Kinit, 20II). This viewpoint relies on the fact that complex work, as that required in the innovation process, gains effectiveness when different intelligences cooperate, therefore, if the interaction among people is facilitated and the barriers removed, there is likely be a steep gain in time and improvement in the quality of innovation efforts. In sum, Web 2.0 may be considered an efficient way of using technology to bring together and combine different knowledges. Open Innovation highlights another important research topic related to collaboration in innovation management: knowledge networks.

\section{Knowledge Networks}

In order to access and combine information, knowledge, competencies, technologies and ideas from internal and external sources in the innovation process, as suggested by the Open Innovation model, players establish formal and informal networks and collaborative arrangements which bring together very different actors: individual researchers, suppliers, clients, other enterprises including competitors, universities and government bodies. These arrangements may be based on informal ties between individuals (Granovetter, 1985), inter-organizational agreements (Oven-Smith; Powell, 2004) or formal strategic alliances legally institutionalized (PowelL, Koput and Smith-Doerr, 1996). Such networks, also called innovation networks, represent an essential component of the innovation process because they channel and direct the flow of information and resources within a complex social structure (Oven-Smith; Powell, 2004). The knowledge networks facilitate information diffusion and knowledge exchange (Mowery et. Al, 2004), critical inputs of the innovation process, besides favoring the co-evolution of the participating players. Engaging in knowledge networks also contributes to the improvement of internal learning mechanisms, fostering the development of new dynamic competencies that amplify the competitive capacity of organizations.

Chesbrough, Vanhaverbeke and West (2006) point out that the capacity to combine internal and external competencies, technologies and knowledge depends, to a great extent, on the firm's investment history in R\&D and the maturity of the internal R\&D activities. Rosenbloom and Spencer (1996) agree that the effective use of external sources of knowledge depends on the scientific and technical capacities of the firm, which reinforces the value of internal R\&D investments. Beside the players' absorptive capacity (Cohen; Levinthal, 1990), the fulfillment of a network's potential faces a handful of other challenges, such as building an institutional environment supportive of cooperation, identifying critical external knowledge and technology, connecting and stimu- lating relevant players to engage in the cooperative venture, defining the optimum structure for the network - number of participants, density of ties, governance etc., and then, effectively establishing the network, generating synergy, combining virtual and physical dimensions in the cooperative effort, establishing goals and performance metrics etc.

Although the rationale for the adoption of innovative management models seems clear, its materialization still requires overcoming tangible and intangible barriers concerned with existing resistance to cooperating and openly interacting usually found in social organizations (Teixeira and Guerra, 2002).

\section{Method}

\section{Design}

From the literature review, the analysis the PCREX method focuses on (i) identifying its alignment with the most recent models of innovation, including networking, which allows the researchers to infer its potential to foster the innovation process (ii) evaluate eight Centers / Networks of Excellence structured according to the PCREX method and (iii) analyze the strengths and weaknesses associated with the application of PCREX in the structuring of R\&D activities.

\section{Procedure}

To accomplish these objectives, firstly, a critical analysis of the PCREX method was carried out, through the examination of documents and interviews with the principal actors involved in its elaboration. The evaluation of the Centers / Networks of Excellence (CNEs) supported by Petrobras was based on field research: structured interviews were conducted with the principal members related to the governance of the eight CNEs chosen for the sample. The research aimed to gather information about the history of the CNEs, their situation at the moment of the research, their most relevant accomplishments and weaknesses.

Figure 4 shows the universe of Centers/Networks of Excellence supported by Petrobras since the PCREX method was approved of by the company directors in 1996. The CNEs in the research sample are highlighted in yellow. The sample was chosen by convenience, using the following criteria for inclusion: the most dynamic CNEs at the time of the research and the CNEs which achieved best results.

\section{Results}

The PCREX Method (Petrobras, 2008) presents guidelines to create permanent R\&D centers or networks which compulsorily bring together enterprises, universities and 
research centers, both national and foreign, in an effort to continuously strive for excellence in a chosen field, be it technological, scientific, social, cultural or educational, so as to foster the development of the participating organizations and society. According to the method's author, PCREX is a management practice that supports the structuring of physical, technological and knowledge based consortiums, focused on reaching and maintaining supremacy in a chosen field. A PCREX CNE is described as a combination of knowledge and physical, financial, technological and methodological resources, which are brought together to solve complex problems and to generate new products, processes or services for the use of the CNE members or for commercialization in the market. At the time of the research, the management of the PCREX method was jointly carried out by Petrobras and the Espaço Centros e Redes de Excelência - Ecentex, from the Federal University of Rio de Janeiro (Coppe-UFRJ).

The PCREX method was introduced with the review of Petrobras 1992-2000 Strategic Plan, approved on September 22, 1992, which included the proposal for the elaboration of 14 Projects to support the company's effort to accomplish the goals established in the Strategic Plan. The Centers of Excellence Strategic Project was one of the 14 items in this portfolio, which means the PCREX was con- ceived in complete alignment with the corporate strategy. The PCREX method has been evolving since its first application, in 1996, to structure the Center of Excellence in Geochemistry, when its concept and specifications were not yet fully developed. The method's present version was released in September 2008. According to this document, the vision of a PCREX CNE is to be considered a model for combining resources and performing at excellence level in a chosen field, focusing on being at the cutting edge of technology and knowledge.

The governance of PCREX ventures can be networked, centralized on the strategic partners, or attributed exclusively to the lead organization (the entity which proposed the creation of the initiative), depending on the agreement of the parties involved. The method suggests that a Management Council and an Executive Committee be set up, the latter being responsible for the CNE management. Depending on the complexity of the case, the method suggests the structuring of a Technical Support Group or a group of recognized experts to advise the $\mathrm{CNE}$ on issues related to its strategy and general guidelines, and facilitate access to advanced knowledge. A PCREX initiative may be a traditional physical organization or a virtual entity; one way or another, it should define its mission, vision and unifying goals clearly.
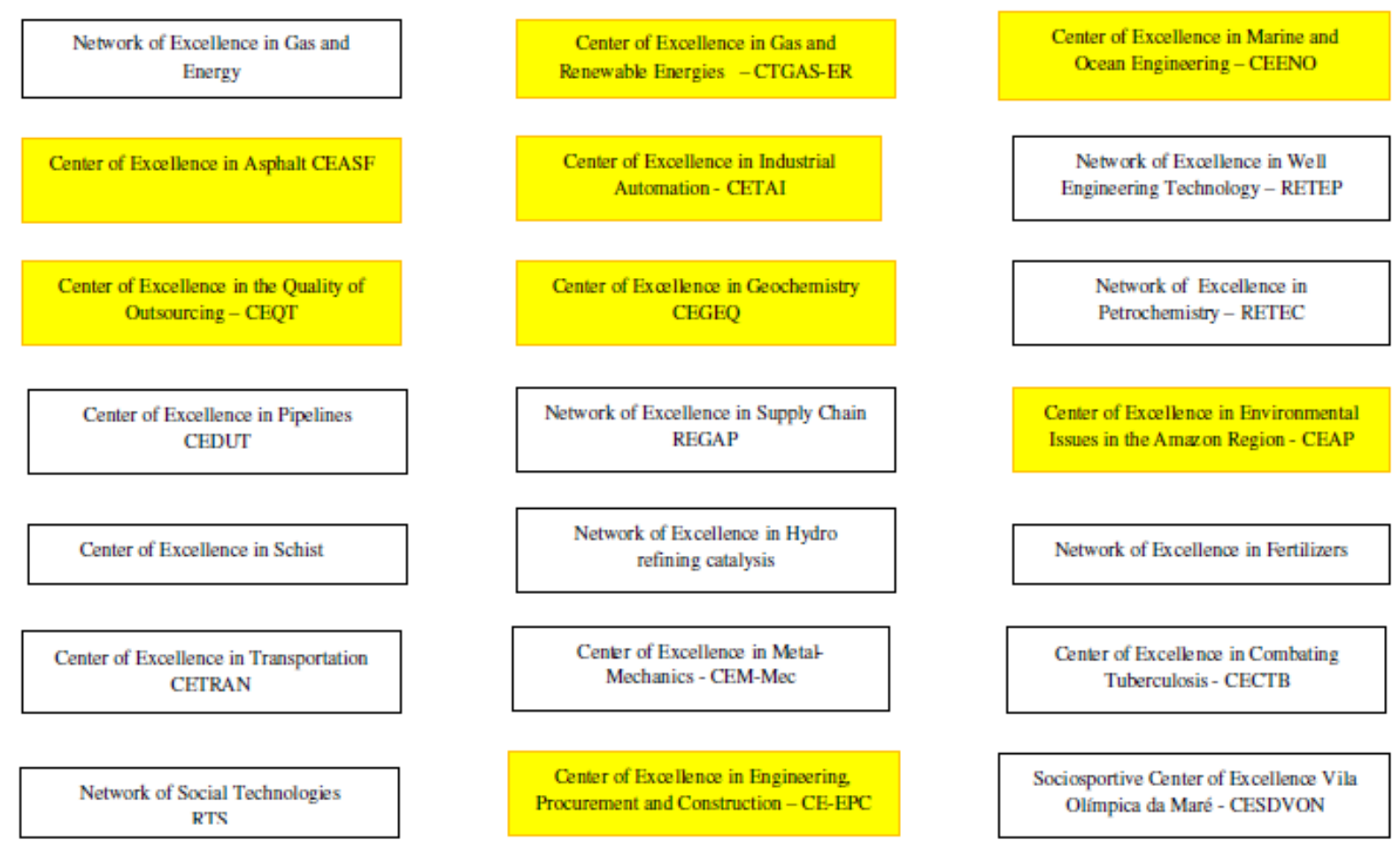

Figure 4: CNE Universe and Sample. Data adapted from Petrobras (2008)

ISSN: 07I 8-2724. (http://www.jotmi.org)

Journal of Technology Management \& Innovation (c) Universidad Alberto Hurtado, Facultad de Economía y Negocios. 
Naming the venture a Center of Excellence or a Network of Excellence depends on the idea its leaders intend to show the market and the society: the denomination Center gives the market an idea of power while the word Network suggests relationships. According to the PCREX method, either Centers or Networks of Excellence consist of a set of partnerships.

This brief presentation of PCREX reveals that the method's concept is very much aligned with what is considered the best current innovation management practices. Figure 6 illustrates the configuration of a CNE with shared control and management, which reinforces its alignment with both the Open Innovation and Knowledge Network approaches.

In sum, the main features of the PCREX method are the following:

- Innovation is seen as part of the firm's business value chain and, therefore, it is deeply associated to a previously identified demand.

- The method recommends the establishment of an interactive model, which connects internal and external players that can contribute to meet the identified demand through innovation.

- The method matches the Open Innovation proposals as it clearly recognizes that the firm is not self-sufficient in all its areas of activities and, therefore, its boundaries must be permeable to external knowledge and partnerships.

- $\quad$ The PCREX model leads to the construction of cooperation networks involving research groups from academia and research centers, suppliers and even competitors, depending on the case.

\section{Centers and Networks of Excellence (CNE): strengths and weaknesses}

The establishment of each CNE in the research sample was due to varying motives. There are ventures which happened (i) after long-term relationships between Petrobras, Universities and Research Centers (Center of Excellence in Geochemistry - CEGEQ and Center of Excellence in Industrial Automation - CETAI); (ii) as the company's response to specific challenges (Petrobras Center of Excellence on Environmental Issues in the Amazon Region - CEAP, Center of Excellence in Gas and Renewable Energy Technologies CTGAS-ER, Center of Excellence in Engineering, Procurement and Construction - CE-EPC, Center of Excellence in Marine and Ocean Engineering - CEENO and Center of Excellence in the Quality of Outsourcing - CEQT); or (iii) due to the company's need to integrate internal and external efforts into its knowledge base (Center of Excellence in Asphalt - CEASF).

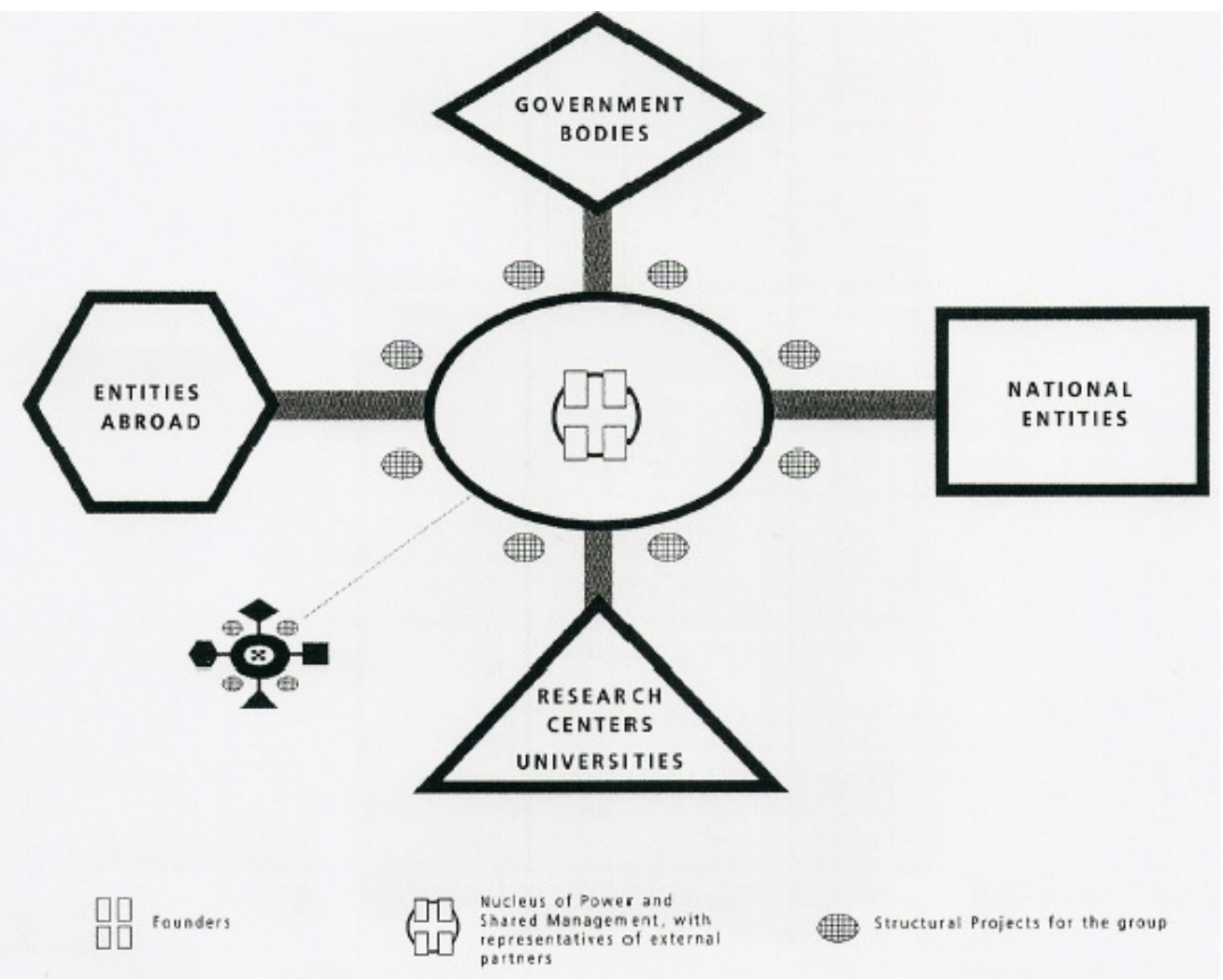

Figure 5 - CNE with shared power and management. Data from Petrobras (2008)

ISSN: 07 I8-2724. (http://www.jotmi.org)

Journal of Technology Management \& Innovation (C) Universidad Alberto Hurtado, Facultad de Economía y Negocios. 
The driving force for the setting up of the two pioneer CNEs, CEGEQ and CETAl, was the cooperative activity already in place between Petrobras and research and education institutions. CEGEQ, in particular, was responsible for the intensification of the internationalization of the company's activities in geochemistry in the 1990's. Through the development of research projects and the provision of geochemistry services, such as the evaluation of the oil potential of sedimentary basins in Latin America, Africa and Middle East, the former partnership between Petrobras Geochemistry area and the Engineering Post-Graduate Institute of the Federal University of Rio de Janeiro (Coppe/UFRJ), started in the 1970's, evolved to a new dimension, bringing to life Petrobras's first CNE. CETAI was designed to meet the company's challenges in Industrial Automation, mainly posed by the refining area. The already existing cooperative activities between the company's related area and the University of São Paulo (USP) were consolidated into the establishment of CETAl.

Different challenges faced by the company generated the creation of the other CNEs. CE-EPC was created in 2008, within the Program for the Mobilization of the National Oil and Natural Gas Industry (PROMINP) to develop solutions for the problems faced by the EPC (Engineering, Procurement and Construction) industry related to the oil, gas and energy sectors in Brazil, problems which affect competitiveness in the industry.

The company's concern about the high risk of environmental accidents in the oil production areas in the Amazon Region motivated the proposition and installation of Petrobras's Center of Excellence on Environmental Issues in the Amazon Region (CEAP) in 2007. CEAP brought together a large number of local R\&D projects, among which the Piatan Project - Oil Industry Strategic Socio-environmental Intelligence in the Amazon Region, a very broad R\&D initiative initiated by researchers from the Federal University of Amazônia (UFAM) in 1999.

The demand for local investments in a Gas Chemical Pole (a project which did not succeed) presented to Petrobras by the government of Rio Grande do Norte (RN), a small state in northeastern Brazil, contributed significantly to the installation of the Gas and Renewable Energy Technologies Center (CTGAS-ER) in RN, as a compensation venture for the original demand. The creation of CTGAS, the CNE's former name, was part of the Brazilian government's effort to foster the natural gas industry in the country. The CTGAS-ER is dedicated to (i) improving operations related to the distribution of natural gas (ii) developing the market for natural gas in Brazil and (iii) after 2006, carrying out research in the field of renewable energy.
The Center of Excellence in Marine and Ocean Engineering (CEENO) was institutionalized in 2002 from an existing R\&D network involving three universities, a research center and Petrobras. It focuses on responding to the demands and challenges of the Brazilian marine industry.

Another challenge which gave rise to a CNE was the huge national and international repercussion of a series of oil-related environmental accidents at the beginning of the 2000s, such as oil leaks (spill) in Guanabara Bay and in the Paraná Refinery, the sinking of an offshore oil rig, among others. The efforts to identify the causes of the accidents led to an internal review of the quality of the company's outsourcing process. As a consequence, in May 2005, the Center of Excellence in the Quality of Outsourcing (CEQT) was created, based on partnerships with enterprises, universities, and public and private entities, aiming at (i) broadening the company's relationship network and (ii) reinforcing the corporative policies and guidelines concerning the quality of outsourcing.

The Center of Excellence in Asphalt, the last CNE in the sample, evolved from a research group in paving, originally based in the refining area of the company. In 2000, after eleven years of research activities, the integration of Petrobras activities in the field and the inclusion of external organizations in a networked effort to improve the paving process in Brazil led to the setting up of CEASF.

As for their status at the time of research, the eight CNEs studied can be grouped in four categories: CE-EPC - active / a public interest civil society organization (OSCIP); CEAP - being restructured / part of the company structure; CETAI and CTGAS-ER - active / partnerships (agreement or consortium) between Petrobras and another institution; CEENO, CEASF, CEGEQ and CEQT - inactive.

\section{Centers / Networks of Excellence (CNEs) Strengths}

At the time of the research, the eight CNEs studied showed different maturity levels, which are reflected in the different levels of relevance of their achievements. For example, the CE-EPC was in its second year of activities and, therefore, still in the consolidation phase so its results were still very incipient. Table I presents the most important achievements of each of the eight CNEs studied.

From the list presented in Table I, it can be seen that the ventures' efforts were not only devoted to R\&D, but also to training in their areas of expertise. The emphasis on education was highly appropriate and relevant considering the expressive growth of the research fields in Brazil at the beginning of the 2 Ist century. 


\begin{tabular}{|c|c|}
\hline CNE & Achievements \\
\hline CE-EPC & $\begin{array}{l}\text { - Approaching } 84 \text { relevant players in the EPC industry in Brazil, including operators, suppliers, universities, research } \\
\text { institutes and professional associations. } \\
\text { Availability of physical and virtual spaces to foster interaction and cooperation between participants. } \\
\text { - } \\
\text { Development of a project portfolio (most of the projects were still in the initial stage of development) } \\
\text { Online training for community members. }\end{array}$ \\
\hline CETAI & $\begin{array}{l}\text { Development of advanced control and performance monitoring systems: benefits of US\$ } 60 \mathrm{MI} / \text { year. } \\
17 \text { ongoing projects in the areas of R\&D, implementation and training, involving several universities and companies. } \\
\text { Six new projects under consideration for funding in Petrobras. } \\
\text { Publication of articles in national and international journals. } \\
\text { Conducting specialization course in process control and optimization: } 30 \text { engineers qualified between } 2005-2007 \text {. }\end{array}$ \\
\hline CEAP & $\begin{array}{l}\text { Development of Chico Mendes Robot, a hybrid device for environmental monitoring which is able to pick samples } \\
\text { from places which are hard to access in the Amazon Region, without damaging environmentally sensitive areas. } \\
\text { Training of around } 200 \text { professors and researchers from local universities in project management systems. } \\
\text { Creating a broad database about the Amazon region, consolidating information generated in many years of research, } \\
\text { including projects prior to the institutionalization of CEAP. }\end{array}$ \\
\hline CTGAS-ER & $\begin{array}{l}\text { - } \\
\text { Conducting } 42 \text { technical courses. } \\
\text { gevelopment of new technologies, especially the GERADIS: a software for assessing the potential market of natural } \\
\text { Das to drive distributed generation. } \\
\text { Development of a low power energy cogeneration unit. } \\
\text { Offer of a test site for natural gas meters in operational conditions. } \\
\text { Development of various partnership projects involving Basic Industrial Technology for the natural gas area. }\end{array}$ \\
\hline CEGEQ & $\begin{array}{l}\text { Development of remote sensing technology for oil exudation. } \\
\text { Public offer of a strict sensu post-graduation course in Petroleum Systems. } \\
\text { Increased experience of staff in the interpretation of petroleum systems in Brazil and abroad and training of qualified } \\
\text { technical staff. } \\
\text { sion of modern technology to solve geochemical problems in oil exploration and production (E\&P) and environmental geology. }\end{array}$ \\
\hline CEASF & $\begin{array}{l}\text { Teacher training in paving technologies in Rio de Janeiro, Curitiba, Fortaleza, São Paulo, Salvador, Belo Horizonte and } \\
\text { Porto Alegre. } \\
\text { Equipping laboratories at several universities. } \\
\text { Investment in equipment and infrastructure improvement at several Brazilian universities. } \\
\text { Graduating masters and doctors in asphalt technologies. } \\
\text { Research support through the provision of full-time researchers in asphalt. } \\
\text { Attraction of undergraduate students to the area and systematic offer of courses. } \\
\text { Generation of employment opportunities. } \\
\text { Development and publication of technical papers, mainly teaching materials for the improvement of technical training } \\
\text { on paving in the country. } \\
\text { Development of equipment for the paving industry. } \\
\text { Creating a portal for knowledge dissemination and support for the achievement of CEASF goals. } \\
\text { Development of a measurement system for the network activities on a regional base (network thermometer), using a } \\
\text { common set of indicators. }\end{array}$ \\
\hline CEENO & $\begin{array}{l}\text { Development of projects from the Numerical Test Tank research group and the area of Ocean Engineering at USP. } \\
\text { Development of a Technological Training Program for the Shipbuilding Industry, enabling studies for a technological di- } \\
\text { agnosis of the sector in the country and the identification of global best practices in building and management in the shipbuilding } \\
\text { industry. } \\
\text { - } \\
\text { - } \\
\text { - }\end{array}$ \\
\hline CEQT & 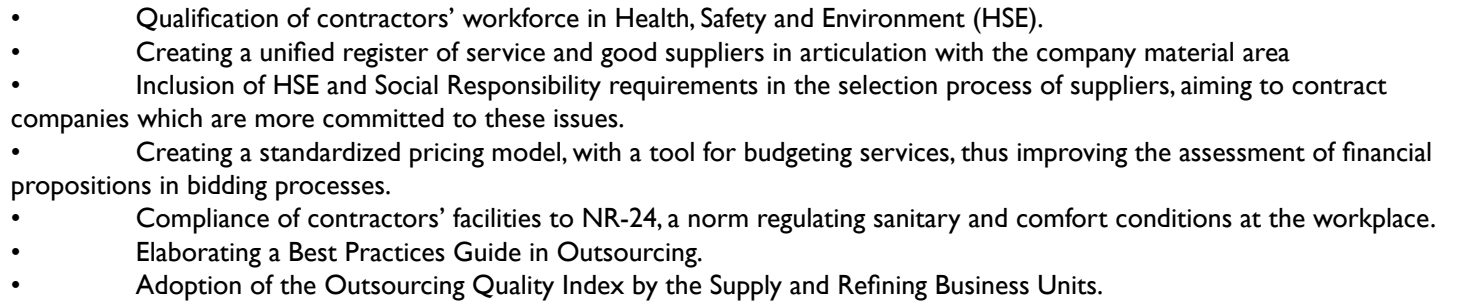 \\
\hline
\end{tabular}

Table I: CNE achievements. Data from direct research with the CNE

ISSN: 07 I8-2724. (http://www.jotmi.org)

Journal of Technology Management \& Innovation (c) Universidad Alberto Hurtado, Facultad de Economía y Negocios. 
Among the RD\&l results, some special achievements were:

- $\quad$ The development of Chico Mendes Robot, a hybrid device for environmental monitoring which is able to pick samples from places which are hard to access in the Amazon Region, without damaging environmentally sensitive areas. Chico Mendes Robot gained great international acclaim for its innovative nature.

- $\quad$ The results achieved by CETAI in industrial automation generated significant tangible economic gains for the company.

- $\quad$ The work done by CEGEQ, including the knowledge it produced, positioned the company as a world leader in geochemistry applied to oil exploration and is considered of great importance in the discovery of the subsalt reserves. Although these results may be questioned, they show that the structuring of PCREX model CNE represents a viable alternative for expanding and potentiating the company's internal R\&D activities.

\section{Weaknesses}

The field research revealed the main barriers faced by the CNEs studied. The researchers consider that overcoming the identified obstacles is an essential condition for the consolidation of the CNEs as an effective open innovation strategy for dealing with R\&D challenges.

\section{Informality}

For different reasons, some CNEs were not able to build a stable institutional structure, which has been causing severe difficulties for prospecting, capturing and retaining resources, and also for managing the initiatives and consolidating partnerships.

\section{Resistance to network}

Despite the acknowledged support offered by Petrobras internal departments for the structuring of CNEs, there is a general lack of knowledge and methods for developing networking abilities; therefore, both the prospection of relevant partners and the cooperation dynamic did not achieve reasonable levels of efficiency. The efforts to train managers to articulate and manage collaborative research networks were incipient.

\section{Regulatory environment}

Difficulties concerning regulation, either related to the formalization of consortiums and access to funding, or Petrobras legal status, impose barriers for the operation of the CNEs. Being a public enterprise, Petrobras faces restrictions concerning the use of resources and the contracting of partnerships with other enterprises.

\section{Competition with the Thematic Networks}

New rules from the National Oil and Gas Agency (ANP) have obliged Petrobras to invest $1 \%$ of the gross revenue of its reservoirs with high production volume and high profitability in R\&D,. The amount of money the company does not use must return to ANP.The law determines that up to $50 \%$ of the money be invested in Petrobras sites and the sites of its affiliates and the companies it controls, and at least $50 \%$ be invested in projects and programs developed by/with accredited universities and/or research centers. To match ANP requirements, Petrobras R\&D Center (CENPES) proposed the structuring of Thematic Networks composed exclusively of scientific and technological institutions. The participation of other companies in the projects funded with ANP resources is forbidden thus CNEs cannot access these resources because their projects involve companies. The researchers understand that the emergence of the Thematic Networks (TN) was one of the main causes for the weakening of both the CNEs and the PCREX model of innovation management, as TNs represented an easier way for universities to access large financial resources.

\section{Lack of institutional support}

Although the PCREX method integrates the company's management practices portfolio, there is a clear lack of definition, on the part of the company top-level managers, of the recognition of the CNE initiatives and the program's future guidelines.

\section{Knowledge management and joint agenda}

The lack of a joint agenda which aligns the PCREX method with the company's strategic interests, together with the prevailing traditional approach of conducting non-systemic specific collaborative projects, have hindered the emergence and development of more structured collaboration initiatives.Another common feature of the CNEs studied was the absence of the use of best practices concerning knowledge management and accountability, which hampers the evaluation and diffusion of the ventures' achievements, the dissemination of the new knowledge generated and the intensification of inter-institutional cooperation.

\section{Discussion}

Both the theory and practice highlight that the most advanced models of innovation management struggle to overcome the "offer" approach, which understands innovation as a simple, linear, sequential process pushed by the generation of new knowledge. The new innovative models recommend, on the one hand, involving all the organization in the innovation process and, on the other hand, articulating and 
interacting with a diversified set of external players: clients, suppliers, universities, research centers and even competitors. In order to consolidate this intense internal and external articulation, companies have to build collaborative arrangements and networks, both formal and informal, to systematize and facilitate the relationships and the knowledge exchange among the various actors.

This article presents the analysis and evaluation of an innovation management practice which has been in place at Petrobras since 1996: a method for structuring Centers and Networks of Excellence (PCREX). The researchers observed that PCREX is consistent with the most advanced practices in innovation management, such as Open Innovation. The original idea was that the company could boost its innovation process by setting up PCREX Centers and Networks of Excellence in relevant themes, through which it would be able to access the partners' knowledge resources more easily.

The research reported in this paper revealed that the use of the PCREX model has led to positive results, despite the barriers faced by the initiatives. This observation indicates that the PCREX method can be used to face R\&D problems and challenges whose solution depends heavily on the aggregation of knowledge distributed inside the company and held by other players, among which universities, research institutes, clients, suppliers and competitors figure.

The research identified difficulties that management collaborative models may confront; understanding such challenges may contribute to improve the PCREX method. Firstly, it is evident that a clear articulation between the new models of innovation management, the company's general strategy and its technological strategy in particular is needed. This articulation becomes even more relevant when one considers the challenges to be faced in the relationships within a network of actors who hold very diverse goals. Secondly, the models, initiatives and achievements must be intensely publicized in order to gain greater adherence of both the technical and managerial bodies for the new proposals. From this perspective, the explicit support of the top management for testing new models is an imperative for the consolidation of organizational innovations. Thirdly, people engaged in management models based on intense articulation should be trained to manage networks and develop abilities to break resistance to this kind of action. Fourthly, considering that collaborative arrangements involve a diverse set of actors, the adoption of an institutional model which assures the initiatives and projects more independence and autonomy is of extreme importance. Such models should allow the configuration of hybrid governance structures which are agile enough to match the constantly varying demands for resources. Last but not least, the research revealed the fundamental role of the adoption of best practices of knowledge management and accountability for the success of collaborative models of innovation management. In this sense, the use of Web 2.0 tools and systems may be a solution for the effective appropriation of the full potential of new management models.

\section{References}

CHESBROUGH, H. (2006). Open Business Models: How to Thrive in the New Innovation Landscape. Harvard Business Scholl Press, Cambridge, MA.

CHESBROUGH, H.; Vanhaverbeke,W.;West, J. (2006). Open Innovation: Researching a New Paradigm. Oxford University Press, Oxford, UK.

COHEN,W.M.; Levinthal, D.a. (1990). Absorptive Capacity:A New Perspective on Learning and Innovation. Administrative Science Quarterly, Special Issue:Technology, Organizations, and Innovation. 35(I), I28-I52.

GRANOVETTER, M. (1983). The strength of weak ties: a network theory revisited. Sociological Theory, I, 20 I-233.

HUIZINGH, E. (20I I). Open innovation: State of the art and future perspectives. Technovation. 3 I (I), 2-9.

MOWERY, N., Sampar, Z., Sampat, B., Ziedonis, A. (2004). Ivory tower and industrial innovation: universities-industry technology transfer before and after the Bayh-Dole Act. Stanford University Press, Stanford, CA.

OVEN-SMITH, J., Powell, W.w. (2004). Knowledge networks as channels and conduits: the effects of spillovers in the Boston Biotechnology community. Organization Science. 15 (I), 5-2I.

PETROBRAS. (2008). Metodologia Centros e Redes de Excelência. Rio de Janeiro. http://ecentex.org/bibliografia/livreto_final.pdf [Acessed March 2I, 20I3]

POWELL, W.W.; Koput, K.w.; Smith-Doerr, L. (1996). Interorganization collaboration and the locus of innovation: Networks of learning in biotechnology. Administrative Science Quarterly, 4I, II6-I45.

ROSENBLOOM, S., Spencer, W.j. (1996). Engines of Innovation. Harvard Business School Press, Cambridge, MA.

ROTHWELL, R. (1994). Towards the Fifth-Generation Innovation Process. International Marketing Review, I I I ), 7-3I.

STANDIN, C. e Kinit, S. (20II). How can organizations use wikis for innovation? Technovation, 3 I (7), 287-295. 
J.Technol. Manag. Innov. 2013,Volume 8, Special Issue ALTEC.

TEIXEIRA, F. e Guerra, O. (2002). Redes de Aprendizado em Sistemas Complexos de Produção. Revista de Administração de Empresas, 42(4), 93-105. 